\title{
Utilizing Edmodo in Writing Class: Why and How?
}

\author{
Wensi Alka ${ }^{1}$, Atik Umamah ${ }^{2}$ \\ Faculty of TeacherTraining and Education, Universitas Islam Malang \\ alkawensi@gmail.com, atikumamah@unisma.ac.id
}

\begin{abstract}
This paper comes up to discuss the theories and previous studies about using Edmodo in writing class. Using a social network system in the Industrial era 4.0 helps teaching and learning activities become more productive because students can learn in and outside the class. Thus, it is helpful, especially in writing class, which require long learning time to use this kind of application. Therefore, utilizing online applications in writing class can help students to improve their writing skill and to make learning time more efficient. One of the online applications that are widely used in writing is Edmodo. Generally, this paper then will discuss the method, explanation of writing processes, problems in writing, explanation about learning media, description of the online application, description of Edmodo,benefits of Edmodo, and how to apply Edmodo in writing course. Some previous research highlighting the effect of Edmodo on student's writing skill is the next discussion. Teaching and learning process becomes more active after applying Edmodo. This paper finally gives a conclusion and pedagogical implication as to the closing.
\end{abstract}

Keywords: writing class, online application, Edmodo

\section{INTRODUCTION}

In the era of Industrial Revolution 4.0, the learning process, especially in writing, can be done by utilizing technological sophistication such as online applications. This aims to make the teaching and learning process more effective and efficient. It is in line with Alonso et al. (as cited in Purnawarman et al., 2016) who say that "Teaching paradigm has radically been changed by technology which makes teaching simpler without time and space restriction” (p. 242). In this modern era, writing also employs loaded media like multimedia platforms (Westwood, as cited in Purnawarman et al.,2016). Not few students argue that writing as a complicated and challenging subject because they often have difficulties in writing like in developing ideas; moreover, they have limited time in class. Not only that, but Purnawarman et al. (2016) also state that lack of interest in writing courses is also a problem for students. Therefore, to solve these problems, utilizing an online application is the appropriate solution so that students get ease in learning. It is because they can carry out their writing class activities not only in the class but also outside the class. Considering the facts above, the writer tries to review some studies on the implementation of an online application $\mathrm{n}$ in the teaching and learning process in writing 
class. It is then expected that this paper will provide more insight into the use of online application for students so that they can improve their skill in writing and can utilize technology properly.

\section{METHOD}

According to Nakanishi (2014), one of the methods which can be used to identify articles is a meta-analysis. Therefore, this study use meta-analysis as a method. This article makes use secondary data, namely current journals on Edmodo. That journal is sought through the process of concluding. There are some databases that are used to analyze several articles to include in the meta-analysis: proQuest, ScienceDirect, Google Scolar. Not only that, but Scopus was also checked.

Firstly, the initial search utilized Edmodoas a keyword. However, not many results are found. Therefore, online application and online learning media as the keywords were used. Also, there are five articles analyzed and retrieved for review.

Secondly, the following there are nine journals that were electronically and manually checked: IJCSI International Journal of Computer Science Issues, Journal of Physical Education and Sports, Script Journal: Journal of Linguistic and English Teaching, Indonesian Journal of Applied Linguistics, Register Journal, Journal of Pedagogy and Teacher Education, International Journal of Emerging Technologies in Learning, Procedia - Social and Behavioral Sciences, and ELT journal. Furthermore, in order to find the theory of the writing process and features of Edmodo, a book and website werealso investigated: Introduction to Academic Writing and https://new.edmodo.com/?go2url=/home.

\section{DISCUSSION}

\subsection{Writing Process}

Writing is one of the most crucial and needed subjects that must be mastered by students. Therefore, students have to learn and understand the one by one step of writing. According to Oshima and Hogue (2007), "the process of writing has roughly four steps." Those steps are prewriting, drafting, revising, and the last one is editing ( Tribbel, 1996, as cited in Adin, 2017). For the first step is prewriting. It includes thinking, taking notes, outlining, brainstorming, and gathering information. However, according to White and Arndt (as cited in Alves, 2008), brainstorming is the best prewriting activity which can be used. The second is drafting. In this step, students will put their ideas into sentences and paragraph. Not only that, but they also concentrate upon explaining and supporting their ideas fully and begin to connect the ideas. The 
next is revising. Students will think more deeply in this step because their writing will be corrected by either the teacher or peer. Students will get comments from the teacher after the assignments have been accomplished, mistakes have been corrected, and suggestions for repair are given (Alves, 2008). Besides, students also can give comments and suggestionto each other. Moreover, then, they also refine their writing. They must make each sentence accurate and connect ideas. The last is editing. In this step, students will check for such things as grammar, spelling, and mechanics. Therefore, to master their writing skills, students must understand the four steps above.

\subsection{Problems in Writing}

Most students say that they often get some problems in writing. There are many problems they have. Fauziati (2015) says that the skill that is hard to be mastered is writing. Students usually get difficulties in generating ideas. Sometimes students can not develop their ideas because of their lack of knowledge, and they get confused about how to write because of lack of vocabulary (Fareed et al., 2016). Also, students do not know how to use proper words. Not only that, but lack of academic writing also is a big problem. The essence difficulties that faced by students are in phoneme cluster, spellings, grammar, mistakes due to the first structure, doubling of a preposition, articles, tenses, appropriate subject, language interference, doubling of vocabulary, wrong use of prefixes, and suffixes (Khan, as cited in Al Mubarak, 2017). Then, students also usually feel bored when learning the writing subject. It is because they do not feel enthusiastic. It is like what Purnawarman et al. (2016, p. 242) who state that “... less enthusiastic about writing as their reason to write is only due to classroom-bound activities...”. Moreover, the learning time in class is limited. Intense learning in class cannot be done because of time constraints in the classroom. That is why most students can not master writing well. Therefore, the teacher must have any ideas to solve those problems, such as using a learning medium.

\subsection{Learning Media}

Learning media are media that are used to support the learning processes more effective and efficiently such as online applications. Saja et al. (2018, p. 14) point out that "the medium is a way of the transmission of message and teaching and learning perspective that brings content to students to reach effective learning." Learning media also provide several benefits that can help students to get ease in learning. According to Ahmadi (as cited in Mabruri et al., 2019), students' thoughts, feelings, and willingness to excite the learning process can be affected by the use of learning media. Besides, Mohan et al. (as cited in Saja et al. 2018) state that learning media can affect the learning process, especially in time management. It is because, through learning media, students are usually faster in understanding the lesson.Thus, learning time 
becomes more efficient. Many kinds of media can be used in the learning process. It can be classified into five types: (1) Visual Media: media that can only be seen, such as: photos, posters, cartoons, and graphics, (2) Audio Media: media which only can be heard, such as, audio cassettes, and radios, (3) Audio-Visual Media: Media which can be heard and seen, such as: sound films, videos, television, and soundslides, (4) Reality Media: real media that can be found in the natural environment, such as: animals, specimens, herbaria, and etc, (5) Multimedia: media which can provide media elements ultimately, such as: animation. Multimedia is identical to computers, the internet, and computer-based learning. Thus, In this modern era, students can use online media as a teaching and learning media such as online applications.

\subsection{Online Learning Application}

Online learning application is a system of education that utilizes information technology in the teaching and learning process. Nowadays, It is beneficial, especially in learning. Cobanoglu (as cited in Miftah, 2018)says that the use of computer and internet technology has had a great and good influence on higher education in this digital era. It is because students can get a lot of information and knowledge from the internet quickly. Also, Hursen and Fasli (2017, p. 22) say that “... social network applications are regarded as highly significant for the selfdirected learning skills for learners". There are many types of online learningapplications. Some of those are Kahoot, Quizizz, Web Based, V-Buddy, and Edmodo. Each English skill can use different online application. For instance, in Grammar subject, Kahoot and Quizizz can be utilized by students and teacher because it has several features which can help students to increase their grammar skill. Next, the example of online applications that can be used in speaking skill is V-Buddy. Rashid et al. (2017) find that this application has a significant influence on teacher and students. Third, for reading skill, students can use Web Based. It has been studied by Zidat and Djoudi (2011), and they find that "the use of Web-Based application can contribute to improving the students' reading comprehension." The final is Edmodo. This application is usually used for writing skill which can help teaching and learning process in writing class. Furthermore, it is essential to use the online learning media in the education world.

\subsection{Description of Edmodo}

One of the applications are used in writing, like the mentioned above is Edmodo. Edmodo was discovered by Jeff O'Hara and Nick Borg since 2008 (Balasubramanian, 2014). Edmodo is an online application that can help the teaching and learning process in and outside of the class. Edmodo can be applied by using a smartphone and website to make an online group of practice (Ekici, 2017). Adin (2017) also states that Edmodo is utilized to supply a modest way 
for teachers to construct the online classroom and build students to communicate with the teacher and the other students whenever and wherever, and is learning medium that provides games, free of advertisements, and also the other distractions. It is like what Kongchan (as cited in Purnawarman et al., 2016, p. 242) points out that "Edmodo is very modesty, almost similar to Facebook, and provides space for teachers, students, and even parents to maximize teaching and learning process." Furthermore, from the definitions above, the writer concludes that Edmodo is a simple learning medium which provides several features that can help students to get ease in learning anytime and anywhere. The following is a display of Edmodo

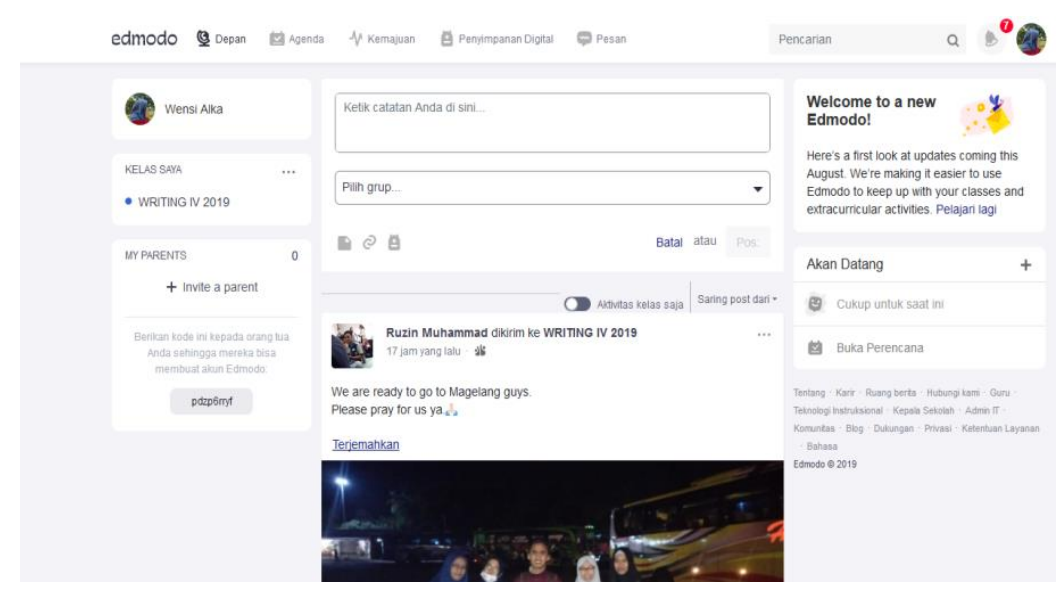

\subsection{The Features of Edmodo}

According to www.edmodo.com, Edmodo has several features to support the learning process.

\section{Polling}

Polling is one of the features that can only be used by the teacher. This feature is usually used by the teacher to find out students' responses about certain things. This Edmodo feature is an excellent way to get instant feedback about a task, and so on.

\section{Assignment}

The assignment is used by teachers to give assignments to students online. This feature comes with the deadline and attaches files feature so that students can submit assignments in the form of a file directly to the teacher. Teachers can directly assess the results of the task that has been done by students. Furthermore, scores given are automatically stored in the grade book features.

\section{File and Link}

In this feature, the teacher and students can send messages by attaching files and links to class groups. The attached file applies to all types of extensions. 
Quiz

The quiz is used to provide an online exam in the form of multiple choice, short field, a matter of wrong, or question about matching the description. The quiz can only be made by the teacher, while students only do it. This feature comes with deadlines. The calculation of scores on each item on the quiz is done automatically for the kind of multiple-choice questions and a short field while scoring a matter of description must be checked by the teacher beforehand.

\section{Gradebook}

The gradebook feature is used as a student grade record. Giving values can be done by the teacher and can be filled manually or automatically. however, filling in values automatically can only be done based on the results of the Assignment and Quiz scores

\section{Parent codes}

This feature serves to provide an opportunity for parents of each student to join in monitoring the learning activities and achievements of their children; the teacher must access the code for the parents of the students and then share it to each parent.

\section{Library}

This feature is used as a place to store various learning resources with diverse content. With the library feature, teachers can upload teaching materials, material, presentations, reference sources, images, videos, audio, and other digital content. Links and Files contained in the Library can be shared with both students and groups. Students can also add content shared by the teacher into the library. This feature can be used as a medium to accommodate various sources from inside and outside so that students can store various information from outside but still be accessed through Edmodo.

\section{Award Badges}

This feature is used to give an award to both students and groups. Awards can be determined by the teacher itself so that it does not prevent the creativity of the teacher in giving awards.

\subsection{The Benefits of Applying Edmodo}

Online learning media have their positive effects to support the learning process. Other learning media usually only can encourage students' enthusiastic about learning. However, different from Edmodo, Edmodo not only improves students' interest, but all of the class activities in a 
classroom also can be done outside the classroom. Based on some studies, Edmodo provides several distinct benefits to advance the learning process.

\subsubsection{In terms of time}

Edmodo can provide students unlimited space and time for learning like learning by smartphone and learning in spare time (Purnawarman et al., 2016). Miftah (2018, p. 40) also points out that “... students can send a message attached with a file and a link, store and share content, e.g., a file or a link, submit homework, assignments, and quizzes, receive and reply their teacher's feedback, messages, alerts, vote on polls as well as set their calendar". Therefore, students certainly can do their classroom activities outside the class whenever and wherever they want.

\subsubsection{In terms of communication}

By using Edmodo, students and teacher also will get closer toeach other. This application enables students to collaborate with peer and their teacher in the class and also outside the class (Balasubramanian et al., 2014). They can learn and communicate with their teacher and friends everytime and everywhere. It is like what Miftah (2018) states that students, teacher, classmates, and their small group can connect each other through Edmodo. It is like what Puspitaloka et al. (2018) state that by using Edmodo, teacher and students will communicate one and another by sharing ideas, problems, and helpful tips. Furthermore, through Edmodo, students and teachers are facilitated in communication.

\subsection{How To Apply Edmodo}

According to the research that was conducted by Daelani (2017), there are three steps in using Edmodo in writing class. Those steps are preparation, teaching, and learning process and evaluation.

\subsubsection{Preparation}

Preparation is crucial if a teacher wants to teach students. In this step, the teacher must prepare the materials and references, make the semester subject plan, and arrange some activities that will be done in class. Furthermore, the teacher gives more practice than theory.

\subsubsection{Applying Edmodo in the learning process}

The teacher has four steps to teach students. There isan introduction, delivering materials, giving assignments in Edmodo, and providing feedback.

\subsubsection{Introduction}


In this step, the teacher introduces the definition, function, features, and also advantages of Edmodo till how to use this application. Not only that, butthe teacher also do practice in front of students how to utilize the features; for instance, what kind of features which can be used to submit the assignments, etc.

\subsubsection{Delivering materials}

According to Daelani (2017), there are two types of delivering materials. They are delivering materials in the class and delivering material on the Edmodo application.

- Delivering materials in the class

Teaching and learning run as usual. The teacher will teach the students about the materials. Then, the teacher explains the materials then gives the exercise that related to the material taught. Also, the teacher guides to finish students' assignment.

- Delivering materials on Edmodo application

The materials that are given by the teacher on Edmodo is additional materials related to the material which havebeen discussed in the class. The teacher usually posts the materials that must be downloaded by students; moreover, the teacher shares the materials then students have to comment.

\subsubsection{Assignment on Edmodo application}

In this step, students must accomplish the assignments that were given by the teacher. Besides, the teacher also tell students about the deadline of submitting the assignment, time for doing the quiz, total questions, the content character, etc.

\subsubsection{Feedback}

Students' assignments will be commented onby the teacher in this step. The comments give in the class and sometimes on Edmodo. However, students also allow providing comments to their friends' assignments.

\subsubsection{Evaluation}

Teacher evaluates by giving comments in the class or on Edmodo so that students' assignments will be better. Through evaluation, students will know wellhow to implement Edmodo in writing class. Moreover, if students have some problems, the teacher also evaluates it. However, the teacher usually evaluates the problems in the class because it will be more apparent.

\subsection{Previous Study}


The following is the discussion about some previous studies related to utilizing Edmodo in writing class.

The first study was conducted by Miftah (2018) under the title "Utilization of Edmodo as an Online Tool in EFL Writing Class to Increase Students' Writing Ability'. The research was carried out in the English Education Department of State Islamic Institute (IAIN) Palangka Raya that involve 15 Indonesian fourth-year undergraduate EFL students. The instruments that are used in this research are writing tasks, observation checklist, field notes, and questionnaire. This research use quantitative and qualitative methodologies.Based on the result, during utilizing Edmodo in the teaching and learning process, students' involvement increase in the writing class.

The second study was conducted by Al-Jabri et al. (2018) under a title "Promoting Students' Paragraph Writing Using EDMODO: An Action Research."25 pre-intermediate English learners in the foundation program at Arab Open Univesity are the participants of this research. Then, the researchers use a questionnaire and two descriptive tasks as the instruments. The method that is used is action research. The result of the questionnaire confirmed that students strongly agree and have very high attitudes towards Edmodo because it provides much time to communicate outside the classroom. Furthermore, students can get immediate feedback on their assignments.

The last previous study was conducted by Balasubramanian et al. (2014) under the title “ A study on "Student preference towards the use of Edmodo as a learning platform to create a responsible learning environment." The subject is 285 students who study in diploma, degree, and a master at a private university at Selangor district, Malaysia during the 2013 academic year. This study used a quantitative method. Then, the instruments are the survey question that was designed using the RASE ( Resources, Activity, Support, and Evaluation). Also, the result of the study is that students find Edmodo an excellent and user-friendly social learning platform that enables them to enjoy working on an online class.

Based on some previous studies above, it is undeniable that applying Edmodo in writing class is exceptionally appropriate. With this, students have a long time in learning and finishing their assignments outside the classroom. Besides, their engagement in learning improved. They are also more enthusiastic about learning through Edmodo. 


\section{CONCLUSION}

The discussion about using Edmodo in the teaching and learning process has been increased in recent years. Both students and teacher find it easier to carry out the teaching and learning process, especially in writing class. It is because Edmodo provides some benefits that can help to develop effective learning. Talking about the benefits of utilizing Edmodo in writing class, it is divided into two benefits; in terms of time and communication. In terms of time, students will be easier to do all the activities outside of the class, and they can accomplish their assignments whenever and wherever they want. Meanwhile, in terms of communication, both students and teacher will get closer. It is because, through Edmodo, they can share their ideas, problems, and also helpful tips. Some studies have proven that Edmodo is an appropriate application to improve the effectiveness of the teaching and learning process in writing class.Reviewing the theories and studies about the use of Edmodo, it is recommended that teacher use this kind of reasonable application to be applied in the other class such as grammar, reading, and speaking class. Hence, there will be reciprocity between the teacher and students both in the class and beyond the class so that they will get efficiency in learning. Also, to make students more engaged, the teacher shouldgive more assignments and learning activity on Edmodo. Finally, for the next researchers who want to identify related to this study, it is suggested to research by using different methods which are more comprehensive.

\section{REFERENCES}

Adin, F. (2017). The effect of Edmodo on students' writing skill in recount text. International Journal of Pedagogy and Teacher Education, 1(2), 73-79. https://doi.org/http://dx.doi.org/10.20961/ijpte.v1i2.5038

Al-Naibi, I., Al-Jabri, M., \& Al-Kalbani, I. (2018). Promoting Students ' Paragraph Writing Using EDMODO: An Action Research. TOJET: The Turkish Online Journal of Educational Technology, 17(1), 130-143. Retrieved from https://files.eric.ed.gov/fulltext/EJ1165773.pdf

Alves, A. R. (2008). Process Writing. Centre for English Language Studies of The University of Birmingham, (July), 1-22.

Balasubramanian, K., Jaykumar, V., \& Fukey, L. N. (2014). A Study on "Student Preference towards the Use of Edmodo as a Learning Platform to Create Responsible Learning Environment." Procedia - Social and Behavioral Sciences, 144, 416-422. https://doi.org/10.1016/j.sbspro.2014.07.311

Daelani, S. S (2017). A study of the implementation of Edmodo application in writing class in the first semester students of English education department in 2017/2018 academic year. The state Islamic institute of Surakarta, Surakarta, Indonesia. 
Edmodo. (2019, June 17). Retrieved June 17, 2019, from https://new.edmodo.com/?go2url=/home

Ekici, D. I. (2017). The Use of Edmodo in Creating an Online Learning Community of Practice for Learning to Teach Science. Malaysian Online Journal of Educational Sciences, 5(2), 91-106. Retrieved

from http://login.ezproxy.library.ualberta.ca/login?url=http://search.ebscohost.com/login.aspx?di rect $=$ true $\& \mathrm{db}=$ eric $\& A N=\mathrm{EJ} 1142512 \&$ site $=$ ehost-live $\&$ scope $=$ site

Fareed, M., Ashraf, A., \& Bilal, M. (2017). ESL Learners' Writing Skills: Problems, Factors, and Suggestions. Journal of Education \& Social Sciences, 4(2), 83-94. https://doi.org/10.20547/jess0421604201

Hursen, C., \& Fasli, F. G. (2017). The impact of reflective teaching applications supported by Edmodo on prospective teachers' self-directed learning skills. International Journal of Emerging Technologies in Learning, 12(10), 21-34. https://doi.org/10.3991/ijet.v12i10.6993

Mabruri, H., Ahmadi, F., \& Suminar, T. (2019). Journal of primary education. Journal of Primary Education, 8(1), 108-116. Retrieved from https://journal.unnes.ac.id/sju/index.php/jpe/article/view/25391

Miftah, M. Z. (2018). Utilization of Edmodo as an Online Tool in EFL Writing Class to Increase $\begin{array}{llllll}\text { Students' Writing } & \text { Ability. }\end{array}$ https://doi.org/10.18326/rgt.v11i1.37-58

Nakanishi, T. (2015). A Meta-Analysis of Extensive Reading Research. TESOL Quarterly, 49(1), 6-37. https://doi.org/10.1002/tesq. 157

Oshima, A., \& Hogue, A. (2007). Introduction to Academic Writing (Third Edition). Retrieved from http://www.amazon.com/dp/0131933957

Purnawarman, P., Susilawati, S., \& Sundayana, W. (2016). The use of Edmodo in teaching writing in a blended learning setting. Indonesian Journal of Applied Linguistics, 5(2), 242. https://doi.org/10.17509/ijal.v5i2.1348

Puspitaloka, N., Rahmawati, I., \& Sonjaya, D. O. (2018). Edmodo As Educational Social Network in Teaching Course Design of Eyl. Script Journal: Journal of Linguistic and English Teaching, 3(2), 146. https://doi.org/10.24903/sj.v3i2.212

Rashid, R. A., Mohamed, S. B., Rahman, M. F. A., \& Shamsuddin, S. N. W. (2017). Developing speaking skills using a virtual speaking buddy. International Journal of Emerging Technologies in Learning, 12(5), 195-201. https://doi.org/10.3991/ijet.v12i05.6955

Saja, A. (2018). The Implementation of Media in Teaching and Learning of Physical, Sport, and Health Education Subject. Journal of Physical Education and Sports Http://Journal.Unnes.Ac.Id/Sju/Index.Php/Jpes The, 7(1), 13-21.

Zidat, S., \& Djoudi, M. (2011). Web-Based Application for Reading Comprehension Skills. IJCSI International Journal of Computer Science Issues, 8(3), 80-87. 